\title{
POSSIBILITIES TO USE TEXTILE CORD WASTE FROM USED TIRES FOR CONCRETE
}

\author{
Jurgita MALAIŠKIENĖ, Džigita NAGROCKIENĖ, Gintautas SKRIPKIŪNAS \\ Department of Building Materials, Faculty of Civil Engineering, \\ Vilnius Gediminas Technical University, Sauletekio av. 11, Vilnius LT-10223, Lithuania
}

Submitted 08 Dec. 2014; accepted 29 May 2015

\begin{abstract}
The goal of the study was to determine the effect of waste tire cord yarn with attached rubber particles on the properties of concrete made of different types of cement (Portland cement without additives - CEM I, Portland cement with limestone additive - CEM II). The filament waste (added at $0 \%, 2 \%, 4 \%, 6 \%, 8 \%$, and $10 \%$ of the amount of fine aggregate) is water absorbing textile fibre additive with rubber particles, therefore a bigger amount of water is required to prepare the concrete mixture. With waste additive, the density and compressive strength of concrete reduces, but water absorption increases. The forecasted freeze-thaw resistance of concrete with cement type CEM I and recycled tire cord increases and slightly reduces when cement type CEM II is used, however retains similar resistance in about 1000 freeze-thaw cycles. The coefficient of thermal conductivity decreases approx. 35\%, when $10 \%$ of recycled tire textile cord is added to concrete mixture.
\end{abstract}

Keywords: concrete, tire waste, textile cord, density, microstructure, frost resistance, porosity, strength.

\section{Introduction}

Every year about 17 million tons of used tires are disposed of all over the world. These tires do not decompose in the natural environment (Sienkiewicz et al. 2012). Tires are difficult to landfill because they cannot be stowed compactly; besides they create favourable conditions for the breeding of mosquitoes and various rodents. Burning of tires also causes serious concerns locally and regionally as they release dangerous uncontrollable pollutants. Tires are made from rubber $(70-80 \%)$ and also of metal and cord, which provide optimum tire shape and the required characteristics (Pehlken, Muller 2009). Used tires are most often used for: retreating, energy recovery, pyrolysis, product recycling, and material recycling (Sienkiewicz et al. 2012).

Many scientists research the use of waste tires in the production of construction materials. At present used tires are burnt in cement production kilns. Rubber particles obtained from waste tires are used in scientific research and manufacturing of ceramics, asphalt and concrete. Authors Ganjian, Khorami and Maghsoudi (Ganjian et al. 2009) used 5, 7.5 and $10 \%$ chipped and crumb rubber from tires. Chipped rubber was used to replace the coarse aggregates in concrete and crumb rubber was used to substitute sand.
After 28 days of hardening, the compressive strength decreased by $10-23 \%$ in specimens where the coarse aggregates were replaced with chipped rubber and $20-40 \%$ in specimens where part of the sand was replaced with crumb rubber.

The study (Hernandez-Olivares et al. 2002) has shown that used tire rubber added to concrete mixture at up to $5 \%$ does not significantly modify the mechanical properties of concrete, and researchers (Sang Son et al. 2011) have proved that the replacement of the standard aggregate with tire rubber at $1 \%(0.6$ and $1 \mathrm{~mm}$ in size $)$ reduces the compressive strength by about $20 \%$.

Authors M. A. Aiello and F. Leuzzi (Aiello, Leuzzi 2010) used a bigger content of waste tire rubber (25, 50 and $75 \%$ ). In one test, a part of the coarse aggregate was replaced; in another test part of the fine aggregate was replaced. The compressive strength of such concrete decreased by about $50 \%$, but at the same time the density and sound conductivity of the specimens decreased. Therefore, the authors proposed to use concrete with these properties for sound barriers and noise reducing asphaltic mixtures.

The article (Pacheco-Torgal et al. 2012) also describes reliable results of using tire rubber in concrete. The waste

Corresponding author: Jurgita Malaiškienè

E-mail: jurgita.malaiskiene@vgtu.lt 
content ranged from 0 to $75 \%$. In one case tire waste was used to replace fine aggregates, in the other case coarse aggregates were replaced. Similar test results were obtained: the strength tended to decrease, but such concrete can be used for building concrete structures located in the areas of severe dynamic actions like railway sleepers. This material can also be used for non-load-bearing purposes such as noise reduction barriers.

Egyptian researchers investigated the effect of the rubber additives on the density and compressive strength of concrete samples (El-Gammal et al. 2010). Recycled tire rubber waste is a promising material for the construction industry because it is light, flexible, energy-absorbing, sound and heat insulating material. Shredded rubber was used to replace the coarse aggregates. Particle size ranged from 10.0 to $15.0 \mathrm{~mm}$. Crumb rubber was also used to replace the fine aggregate - sand. $100 \%$ of coarse aggregate mass was substituted by shredded rubber and fine aggregate was substituted by crumb rubber at $100 \%$ and $50 \%$ by weight. The rubber additive was found to significantly reduce the compressive strength of concrete specimens. The density of concrete specimens with the rubber additive was lower than the density of specimens without the rubber additive. Specimens with crumb rubber additive have higher density compared to specimens with shredded rubber (El-Gammal et al. 2010). Researchers (Toutanji 1996, Oikonomou, Mavridou 2009) substituted part of the natural aggregate in concrete mixtures with waste tire rubber. Author (Toutanji 1996) determined that the replacement of mineral coarse aggregate by shredded tire chips caused a reduction in both compressive and flexural strength and the relationship between the reduction in concrete strength and rubber additive content was not linear. Positive effects were observed in tests (Oikonomou, Mavridou 2009) where sand was replaced by tire rubber at $2.5 \%, 5 \%, 7.5 \%, 10 \%, 12.5 \%$ and $15 \%$ by weight. Lower chloride ion penetration in cement mortars and in concrete reduces the potential for corrosion of embedded reinforcement, which is of great practical importance. Scientists (Oikonomou, Mavridou 2009) recommended using such products in sound barriers and cement blocks, lightweight concrete walls, as well as in structures exposed to aggressive environments where high resistance to chloride ion penetration is required.

Researchers from Venezuela performed non-destructive testing of concrete specimens (Albano et al. 2005). Ultrasonic pulse propagation velocity was determined in concrete specimens with and without the rubber additive. The results have shown that ultrasonic pulse velocity reduced $19 \%$ in specimens where $5 \%$ of fine aggregate content was replaced with rubber additive. In specimens where $10 \%$ of fine aggregate were replaced with waste rubber the ultrasonic pulse velocity reduced $41 \%$ compared to concrete specimens without the rubber additive.
In specimens where finer waste rubber grains $0.29 \mathrm{~mm}$ in size were used, the ultrasonic pulse velocity reduced $23 \%$ and $56 \%$ respectively subject to $5 \%$ and $10 \%$ replacement of fine aggregate with the waste rubber (Albano et al. 2005). This property is important for the evaluation of concrete structure and defects.

Researchers from China (Zhang et al. 2006) investigated rubber included concrete in terms of shrinkage, frost resistance and permeability. The results have shown that waste rubber particles, due to their soft characteristics, reduce the cement paste shrinkage. Rubber powder in hardened cement paste may significantly improve the frost resistance of concrete. However, due to their rough surface, rubber particles 3-4 $\mathrm{mm}$ in size have a very low positive effect on the frost resistance. The addition of the proper amount of rubber in concrete can reduce the permeability of concrete, but excessive rubber can have a negative effect (Zhang et al. 2006).

Lithuanian researchers (Skripkiūnas et al. 2007, Stankevičius et al. 2007) have also studied the properties of concrete containing waste tire rubber. They have found that mechanical properties of concrete containing waste rubber (compressive and splitting tensile strength) and concrete density depend not only on the waste rubber content but also on water/cement ratio in the mixture. The higher content of waste rubber is only reasonable in cases where low density concrete with high deformability and high frost resistance properties are required. Ground waste rubber reduces the modulus of elasticity of concrete and improves the properties of concrete structure (porosity). The waste rubber included concrete may be used in road and bridge paving and as well as in shock and cracking-resistant, sound-insulating elements (Kerševičius, Skripkiūnas 2001).

There are a number of studies analysing the effect of metal fibres from waste tires on the properties of concrete Centonze et al. 2012, Aiello et al. 2009, Papakonstantinou, Tobolski 2006). In these works were determined, that the compressive strength of concrete with RSF (steel fibres from waste tires) shows a better performance with respect to ISF (industrial steel fibres). The post-cracking behaviour of the RSF, obtained by flexural tests, was comparable with that of ISF. But authors said, that interesting results obtained confirm the promising application of concrete reinforced with RSF; however, further research work is still necessary, extending the investigations to medium and full-scale structural elements, representative of possible practical situations.

In the literature review we did not find any references to tests analysing the use of waste tire cord fabrics. The most similar tests were done in the US (Li et al. 2004a, Li et al. 2004b, Garrick 2005) where yarns from waste tires were used; however the type and dimensions of yarns used in the said tests were different from the yarns used in our 
tests. In these tests (Li et al. 2004a, Li et al. 2004b, Garrick 2005) tires were cut into trips by hand. It was determined, that compressive strength of the rubberized concrete decreases because of the weak bond between the waste tire and concrete matrix. There was approximately $43 \%$ decrease in the compressive strength with the addition of the waste tire chips. Batches, which consisted of waste tires without steel wire, had the lowest split tensile strengths. The concrete without waste tire failed a lot sooner than the rubberized concrete, concrete with rubber is much tougher than concrete without rubber. These researchers ((Li et al. 2004a, Li et al. 2004b, Garrick 2005) done conclusion, that waste tire modified concrete can be used in industrial floorings such as factory and warehouse floors where the increased impact resistance and post-cracking ductility will be beneficial.

The goal of our study was to determine the effect of garnetted waste tire cord yarn on the properties of concrete.

\section{Experimental details}

The main raw material is Portland cement without additives (CEM I) $42.5 \mathrm{R}$ and with limestone additive (CEM II) 42.5 R complying with EN 197-1 requirements. Table 1 presents the basic characteristics of Portland cement.

$4 / 16 \mathrm{~mm}$ gravel, used as the coarse aggregate, meets EN 12620: 2003 requirements. Weak rock (sandstone, limestone, etc.) content does not exceed $2 \%$ by weight.

Aggregates were tested in accordance with EN 10972, EN 1097-3, EN 1367-2, and EN 933-1. Main physical and mechanical properties of the gravel and sand are presented in Table 2.

The properties of tire cord obtained from processed waste tires are presented in Table 3.

The image of waste tire cord yarn is presented in Figure 1 . The waste tire cord yarn was obtained in JSC "Metaloidas" technological equipment by mechanical treatment (grinding, sieving).

The microstructure image was obtained with a Carl Zeiss microscope Evo LS 25. In Figure 1 it is seen that the used waste tire cord yarn has rubber impurities. The size of rubber particles varied from $50 \mu \mathrm{m}$ to $5 \mathrm{~mm}$. The main chemical elements of waste tire cord yarn are oxygen and carbon. The elemental chemical analysis of raw materials and specimens was performed by Oxford EDS microanalyser INCAPenta Fet $\times 3$ combined with the aforementioned microscope. Firstly, the system was vacuumed up to $2.0 \times 105 \mathrm{~Pa}$ in order to define an elemental chemical composition. Then, a tungsten wire was used for $20 \mathrm{kV}$ electron flow to pass to the specimen and penetrate to the depth of several microns. The electron flow strikes the sample and secondary electrons are emitted from the atoms occupying the top surface.
Table 1. Portland cement characteristics

\begin{tabular}{lcccc}
\hline Designation & $\begin{array}{c}\text { Bulk den- } \\
\text { sity, } \\
\mathrm{g} / \mathrm{cm}^{3}\end{array}$ & $\begin{array}{c}\text { Specific } \\
\text { gravity, } \\
\mathrm{g} / \mathrm{cm}^{3}\end{array}$ & $\begin{array}{c}\text { Specific } \\
\text { surface } \\
\text { area, } \\
\mathrm{cm}^{2} / \mathrm{g}\end{array}$ & $\begin{array}{c}\text { Compressive } \\
\text { strength after } \\
28 \text { days, } \mathrm{MPa}\end{array}$ \\
\hline CEM I 42.5 R & 1.2 & 3.2 & 3700 & $54 \pm 3$ \\
$\begin{array}{l}\text { CEM II/A-LL } \\
42.5 \mathrm{R}\end{array}$ & 1.1 & 3.1 & 4100 & $52 \pm 3$ \\
\hline
\end{tabular}

Table 2. Test results of physical and mechanical properties of gravel and sand

\begin{tabular}{lcc}
\hline \multicolumn{1}{c}{ Characteristics } & $\begin{array}{c}\text { Gravel } \\
4 / 16 \mathrm{~mm}\end{array}$ & $\begin{array}{c}\text { Sand } \\
0 / 4 \mathrm{~mm}\end{array}$ \\
\hline Particle density, $\mathrm{kg} / \mathrm{m}^{3}$ & 2650 & 2600 \\
Water absorption, $\%$ & 1.30 & 0.59 \\
Bulk density, $\mathrm{kg} / \mathrm{m}^{3}$ & 1546 & 1582 \\
Resistance to fragmentation, $\%$ & 19.0 & - \\
\hline
\end{tabular}

Table 3. Properties of tire cord

\begin{tabular}{lc}
\hline \multicolumn{1}{c}{ Characteristics } & Results \\
\hline Density, $\mathrm{kg} / \mathrm{m}^{3}$ & 600 \\
Average length, $\mathrm{mm}$ & 7.8 \\
Average width, $\mathrm{mm}$ & 0.011 \\
\hline
\end{tabular}

Superplasticizer Muraplast FK 63.30-W complying with EN 934-2 was used as a technological admixture. Water complied with EN 1008 requirements. Concrete mixture was proportioned in compliance with the requirements of the standards. Concrete mixture composition, density and consistence (value of slump) are presented in Table 4.

The $\mathrm{W} / \mathrm{C}$ ratio was kept constant, but the water content was changed in order to retain the same consistence class and to find out how much water should be added when waste tire cord yarn is used in concrete manufacturing. We found that water demand increased approximately $100 \%$ with the addition of $10 \%$ of waste tire cord yarn (to replace the fine aggregate by weight) to the concrete (Table 4$)$. Specimens $(100 \times 100 \times 100 \mathrm{~mm})$ cubes of the prepared mixtures were kept one day in the forms under normal conditions and later the cubes were immersed in water for 27 days at $20^{\circ} \mathrm{C}$. Concrete specimens for strength testing were made and cured according to EN 12390-2. The compressive strength was tested according to EN 12390-3. The density of concrete was tested according to EN 12390-7. The water absorption was tested according to referenced literature (Mačiulaitis 1996). As water absorption in concrete containing more than $6 \%$ of waste by weight does not stop, we continued to perform the soaking tests after $72 \mathrm{~h}$ stipulated in the methodology (Mačiulaitis 1996). 
The expected frost resistance was determined according to general, open and close porosities. Then the $K_{f}$ factor was calculated from the equation and according to

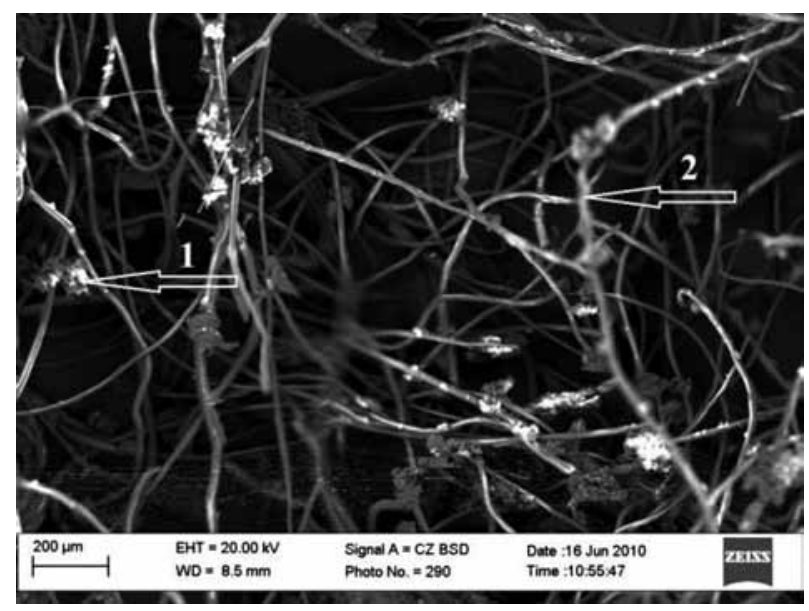

Fig 1 . The image of waste tire cord yarn used in the tests (1 - particles of rubber, 2 - synthetic yarn)

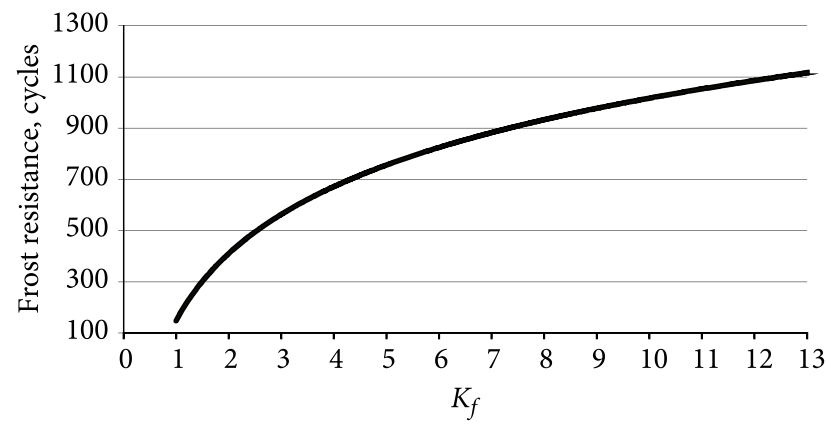

Fig. 2. Frost resistance forecast by $K_{f}$
Figure 2 frost resistance was predicted (Skripkiūnas 2007, Skripkiunas et al. 2008, Nagrockienè et al. 2011):

$$
K_{f}=\frac{P_{u}}{P_{a} \cdot 0.09},
$$

where: $P_{u}$ - closed porosity, $\% ; P_{a}$ - open porosity, $\%$.

The forecasted coefficient of thermal conductivity was determined according to standard EN 1745.

The flexural tensile strength (load-deflection curves) was determined according to EN 14651+A1. Concrete specimens were made and cured according to EN 12390-2. The tests with small specimens $40 \times 40 \times 160 \mathrm{~mm}$ were carried out.

\section{Results and discussion}

The results of concrete mixtures density analysis show that the used waste reduced the density of the mixture $16 \%$ in the case of cement CEM II and 18\% in the case of cement CEM I. Higher density was observed in specimens with type CEM I cement; this can be explained by higher density of the cement (Table 4).

Images of the microstructure of concrete containing $4 \%$ and $10 \%$ of textile cord waste are presented in Figure 3. The images show that the amount of fine closed pores increases with higher waste content in the mixture. These closed pores improve freeze-thaw characteristics of concrete but have a negative effect on the binding of the waste with hardened cement paste leading to lower compressive strength. Microstructure images also illustrate that textile fibre splits into many uniformly distributed finer fibres.

Table 4. Concrete mix proportion and properties of fresh concrete

\begin{tabular}{|c|c|c|c|c|c|c|c|c|c|}
\hline \multirow[b]{2}{*}{ Designation } & \multicolumn{6}{|c|}{ Concrete composition } & \multirow[b]{2}{*}{$\mathrm{W} / \mathrm{C}$} & \multirow{2}{*}{$\begin{array}{l}\text { Concrete } \\
\text { mixture } \\
\text { density, } \\
\mathrm{kg} / \mathrm{m}^{3}\end{array}$} & \multirow{2}{*}{$\begin{array}{c}\text { Concrete } \\
\text { mixture } \\
\text { slump, } \\
\mathrm{mm}\end{array}$} \\
\hline & $\begin{array}{l}\text { Cement } \\
\text { content, } \\
\mathrm{kg} / \mathrm{m}^{3}\end{array}$ & $\begin{array}{c}\text { Gravel } \\
\text { content, kg/ } \\
\mathrm{m}^{3}\end{array}$ & $\begin{array}{l}\text { Sand } \\
\text { content, } \\
\mathrm{kg} / \mathrm{m}^{3}\end{array}$ & $\begin{array}{l}\text { Waste } \\
\text { content, } \\
\mathrm{kg} / \mathrm{m}^{3}\end{array}$ & $\begin{array}{c}\text { Water } \\
\text { content, } \\
\mathrm{kg} / \mathrm{m}^{3}\end{array}$ & $\begin{array}{l}\text { Plasticizer } \\
\text { content, } \\
\mathrm{kg} / \mathrm{m}^{3}\end{array}$ & & & \\
\hline CEM I B0 & 260 & 929 & 957 & 0 & 166 & 1.56 & 0.64 & 2304 & 160 \\
\hline CEM I B2 & 281 & 929 & 938 & 19 & 180 & 1.56 & 0.64 & 2192 & 150 \\
\hline CEM I B4 & 304 & 929 & 919 & 38 & 194 & 1.56 & 0.64 & 2133 & 140 \\
\hline CEM I B6 & 349 & 929 & 900 & 57 & 223 & 1.56 & 0.64 & 2081 & 140 \\
\hline CEM I B8 & 437 & 929 & 880 & 77 & 280 & 1.56 & 0.64 & 1934 & 140 \\
\hline CEM I B10 & 526 & 929 & 861 & 96 & 337 & 1.56 & 0.64 & 1895 & 140 \\
\hline CEM II B0 & 260 & 929 & 957 & 0 & 166 & 1.56 & 0.64 & 2204 & 150 \\
\hline CEM II B2 & 281 & 929 & 938 & 19 & 180 & 1.56 & 0.64 & 2163 & 140 \\
\hline CEM II B4 & 304 & 929 & 919 & 38 & 194 & 1.56 & 0.64 & 2049 & 150 \\
\hline CEM II B6 & 349 & 929 & 900 & 57 & 223 & 1.56 & 0.64 & 1938 & 140 \\
\hline CEM II B8 & 437 & 929 & 880 & 77 & 280 & 1.56 & 0.64 & 1881 & 140 \\
\hline CEM II B10 & 526 & 929 & 861 & 96 & 337 & 1.56 & 0.64 & 1845 & 135 \\
\hline
\end{tabular}



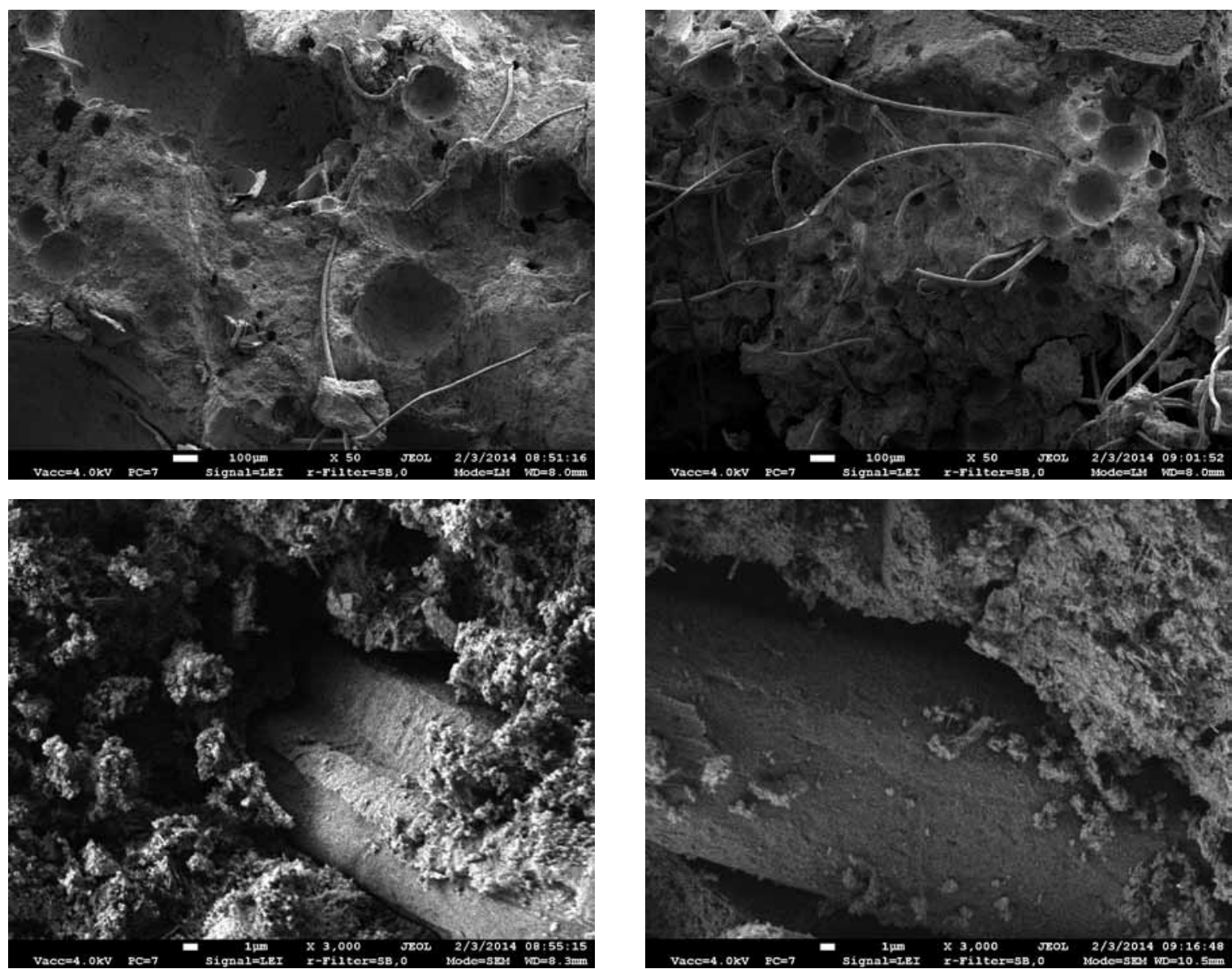

a)

b)

Fig. 3. The concrete microstructure (a) with $4 \%$ textile cord waste, and (b) with $10 \%$ textile cord waste)

The compressive strength of concrete specimens was determined after 7 and 28 days of curing and ultrasonic pulse velocity after 28 days of curing. The test results are presented in Figures 4 and 5. From Figures 4 and 5 we can see that compressive strength and ultrasonic pulse velocity reduce with higher waste content. The compressive strength after 7 and 28 days of curing in specimens with higher waste content becomes actually the same due to the bigger number of pores and voids.

$4 \%$ of waste added to the concrete mixture caused approx. $40 \%$ drop in compressive strength; $10 \%$ of waste caused the drop of $70 \%$ in specimens made of CEM I cement and $80 \%$, in specimens made of CEM II cement.

The change in ultrasonic pulse velocity had small dependence on the type of cement. The addition of $4 \%$ of waste textile cord in the concrete mix reduced ultrasonic pulse velocity only by $3 \%$, whereas $10 \%$ of waste caused a $20 \%$ reduction. This can be explained by the fact that textile cord is a light organic substance of irregular shape that increases the porosity of concrete and the number of air voids.

It also reduces the density and thermal conductivity (Fig. 6, Fig. 10). Density tests results in specimens made of

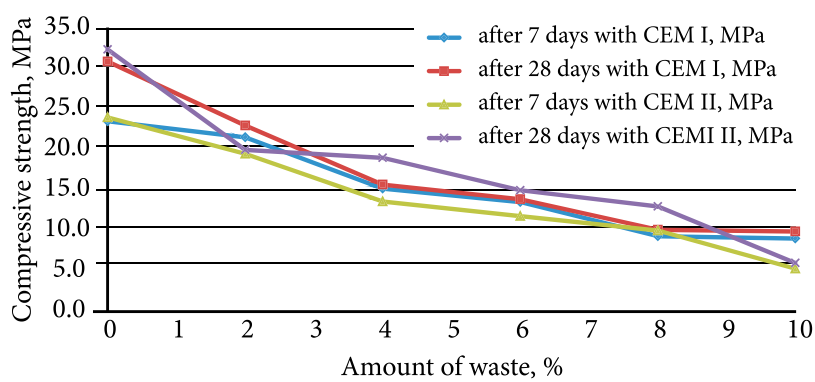

Fig. 4. Compressive strength of concrete after 7 and 28 days as a function of waste amount

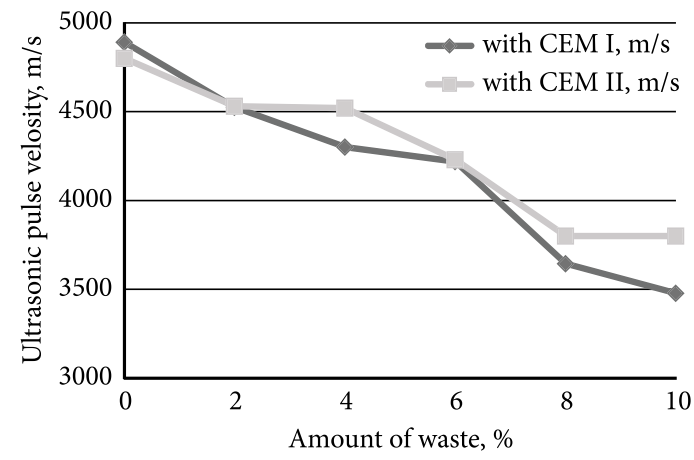

Fig. 5. Ultrasonic pulse velocity after 28 days as a function of waste amount 
different cement types is presented in Figure 6. The density of concrete specimens with CEM I is $10 \%$ higher than in specimens with CEM II, but the trends in density drop are very similar. The most significant drop in concrete density was observed when $4 \%$ of waste was added, whereas $10 \%$ of waste caused $18 \%$ drop in density in specimens made of CEM II cement and $21 \%$ in specimens made of CEM I cement respectively. Water absorption increased with the decrease in density.

Therefore tests were done to determine the change in water absorption with the use of waste tire cord yarn. Figures 7 and 8 demonstrate that water absorption changes

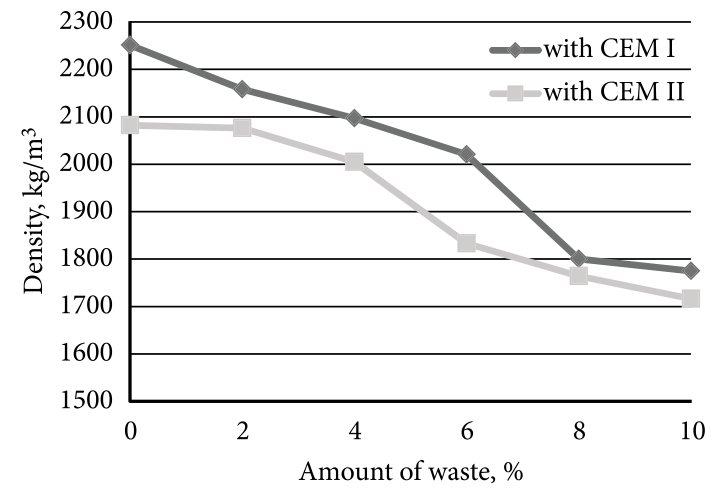

Fig. 6. Concrete density as a function of waste amount

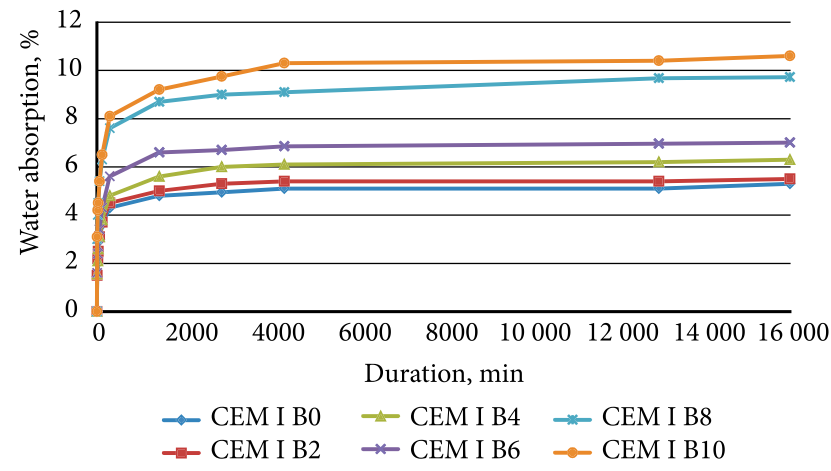

Fig. 7. Water absorption as a function of waste content and soaking time in specimens made of CEM I cement

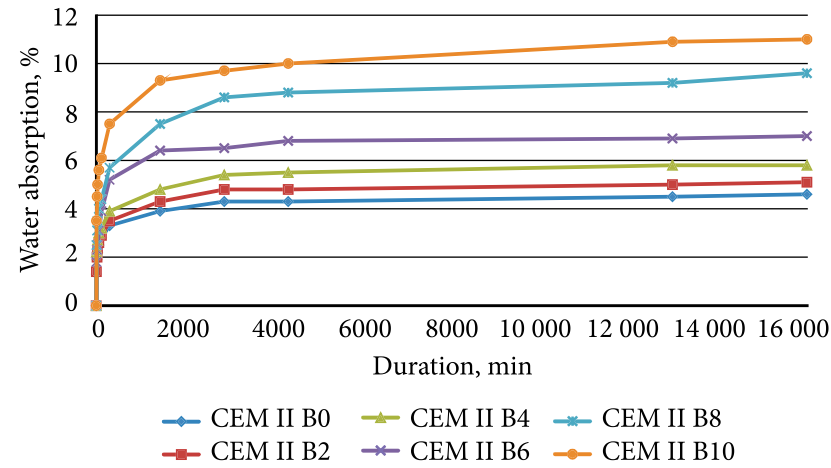

Fig. 8. Water absorption as a function of waste content and soaking time in specimens made with CEM II cement insignificantly from 4.6 to $5.8 \%$ when $4 \%$ of waste is added. The specimens absorbed most of the water during the first few hours and afterwards the absorption almost stopped. The water absorption of concrete containing $10 \%$ waste textile cord with both cement types exceeded $10 \%$ already after 3 days of soaking (Figs 7, 8).

The results of porosity are showed in Figure 9. The waste tire cord yarn reduces the specific density, total and open porosity of concrete, whereas the open porosity tends to increase as well (Fig. 9), especially when type CEM I cement is used. Freeze-thaw resistance is actually determined by the proportion of closed and total porosity. Higher closed porosity of concrete is obtained when type CEM II cement is used. With type CEM I cement the highest closed and open porosity is obtained with $10 \%$ of tire waste.

The forecasting frost resistance of concrete is presented in Table 5.

The comparison of test results with different cement types showed that higher closed porosity and freeze-thaw resistance is obtained in specimens made of type CEM II cement. It can be explained by the fact that specific surface area is bigger in type CEM II cement, i.e. the particles of this cement are finer. As finer particles combine with aggregates better, there are fewer possibilities for internal stress to occur in freeze-thaw conditions or exposure to external forces. The differences in test results are not significant because specific surface areas of the cements differ only by $10 \%$. Freeze-thaw resistance increased $16 \%$

a)

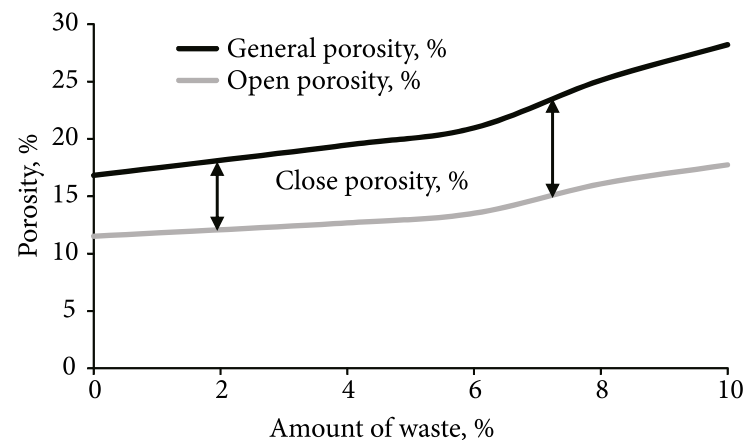

b)

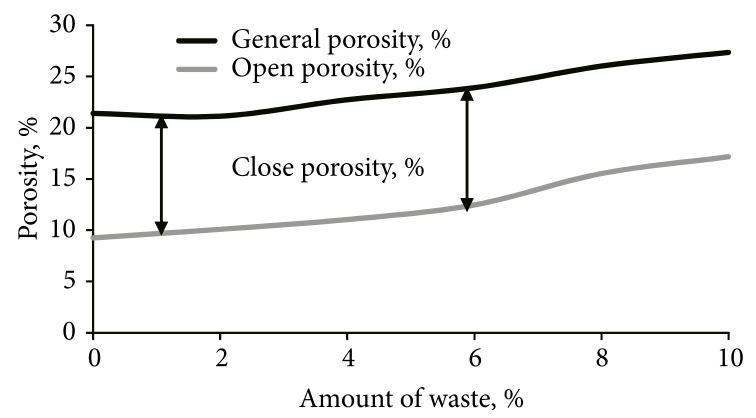

Fig. 9. Porosity of concrete (a) with CEM I, and (b) with CEM II as a function of waste amount 
when waste tire cord yarn was used with type CEM I cement. With type CEM II cement frost resistance increased when waste tire textile cord was added at $4 \%$, and started reducing with higher tire waste content. Although the maximum tire waste content $(10 \%)$ had a significant effect on the drop of compressive strength from 32MPa to $6 \mathrm{MPa}$, the drop in freeze-thaw resistance was much smaller $(17 \%)$. The obtained freeze-thaw resistance is sufficient for the exposure of concrete to external environmental factors.

The results of predicting the coefficient of thermal conductivity are presented in Figure 10. The coefficient of thermal conductivity diminishes almost linearly (dropped $35 \%$ ) with higher tire waste content in the mixture. Thermal conductivity dropped due to lower density caused by the light-weight waste tire cord yarn added to concrete.

The coefficient of thermal conductivity was higher in specimens made of type CEM I cement because of higher density of the cement. Concrete mix with the addition of $10 \%$ of tire waste the coefficient of thermal conductivity in specimens made of type CEM I and type CEM II cements became almost the same (indeed - only $3 \%$ difference in density of the mix). Thus, the effect of cement on the properties of concrete becomes less significant, whereas tire waste has a bigger effect.

Figure 11 illustrates the destruction of specimens with and without waste tire cord yarn additive. Samples without waste tire cord yarn do not bear the load at $0.3 \mathrm{~mm}$ deflection. The addition of waste tire cord yarn to concrete lead to increase the load bearing capacity up to $1.2 \mathrm{~mm}$ deflection.

Comparable trends in the results obtained by researchers (Li et al. 2004a, Li et al. 2004b, Garrick 2005) where yarns from waste tires were used; however the type and dimensions of yarns used in the said tests were different from the yarns used in our tests.
Table 5. Forecasted frost resistance and average specific density of concrete

\begin{tabular}{lccc}
\hline Batch & $\begin{array}{c}\text { Specific } \\
\text { density, kg/m }\end{array}$ & $K_{f}$ & $\begin{array}{c}\text { Forecasted frost } \\
\text { resistance, cycles }\end{array}$ \\
\hline CEM I B0 & 2710 & 5.11 & 760 \\
\hline CEM I B2 & 2470 & 5.75 & 830 \\
\hline CEM I B4 & 2600 & 5.96 & 850 \\
\hline CEM I B6 & 2560 & 6.12 & 860 \\
\hline CEM I B8 & 2400 & 6.18 & 862 \\
\hline CEM I B10 & 2470 & 6.56 & 880 \\
\hline CEM II B0 & 2648 & 11.5 & 1080 \\
\hline CEM II B2 & 2632 & 13.3 & 1130 \\
\hline CEM II B4 & 2594 & 11.8 & 1090 \\
\hline CEM II B6 & 2457 & 11.5 & 1080 \\
\hline CEM II B8 & 2414 & 8.2 & 920 \\
\hline CEM II B10 & 2387 & 7.1 & 895 \\
\hline
\end{tabular}

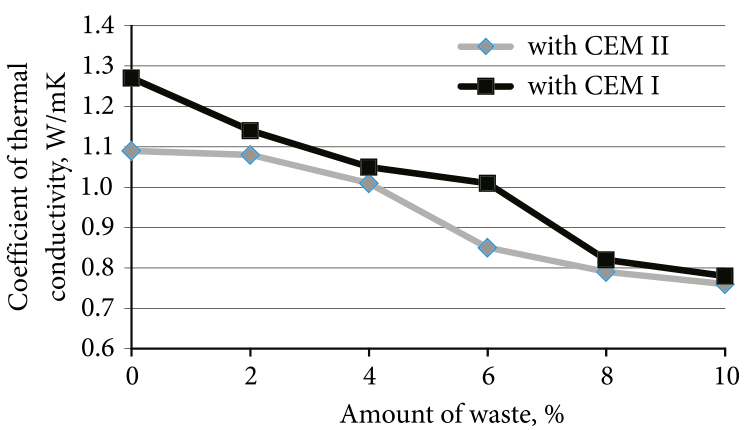

Fig. 10. Coefficient of thermal conductivity of concrete as a function of waste amount

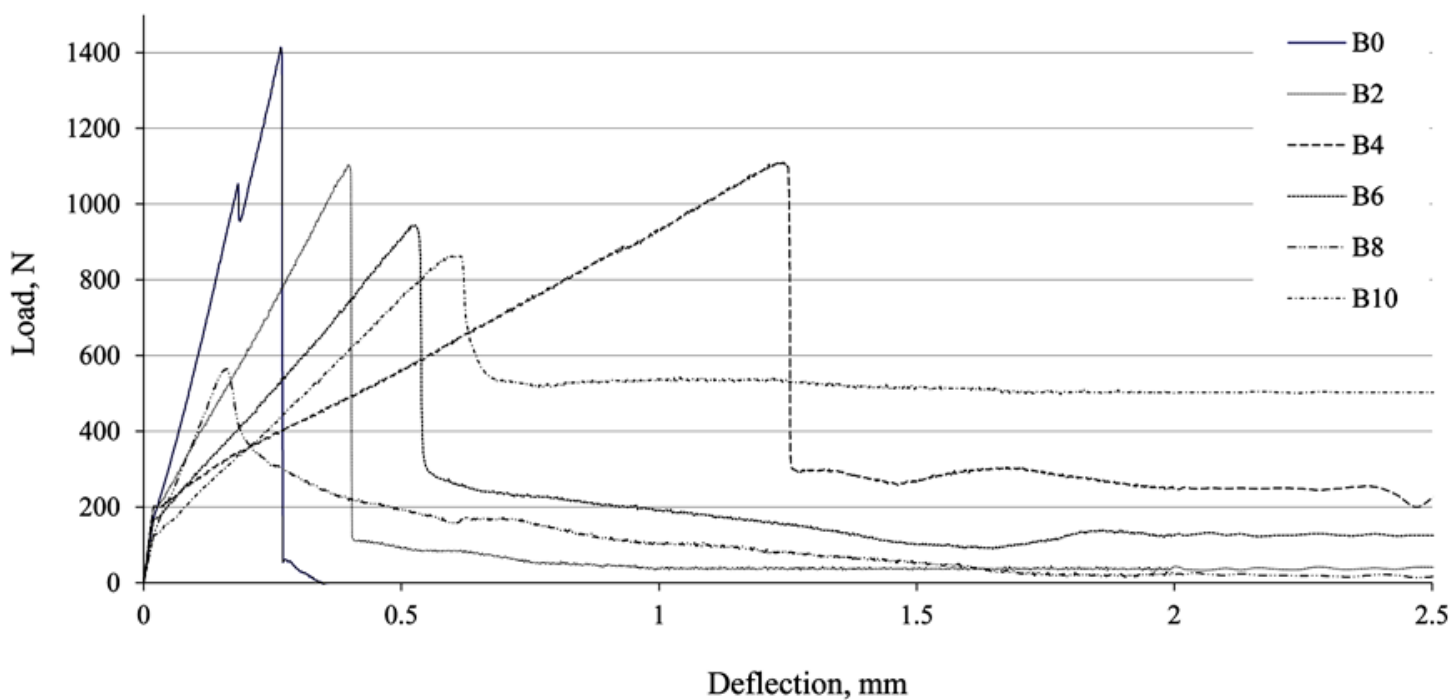

Fig. 11. Influence of waste amount to deflection of concrete 


\section{Conclusions}

The tire cord yarn can be used like addition for concrete. This addition is water absorbing with attached rubber impurities, therefore a bigger amount of water is required to prepare concrete. To keep constant $\mathrm{W} / \mathrm{C}$ ratio a bigger amount of cement was used too. The following conclusions are based on the experimental results:

When waste tire cord yarn was used to substitute $4 \%$ of fine aggregate by mass, water absorption in specimens changed insignificantly from $4.6 \%$ to $5.8 \%$.

The density of concrete dropped about $4 \%$, and ultrasonic pulse velocity dropped $3 \%$; however the compressive strength decreased by $40 \%$. The cement content was increased $17 \%$ to retain the constant $\mathrm{W} / \mathrm{C}$ ratio (0.64).

The forecasted freeze-thaw resistance of concrete made of type CEM I cement with waste tire cord yarn additives increases. The freeze-thaw resistance of concrete made of type CEM II cement with up to $4 \%$ of waste tire cord yarn additives increases, however at higher tire waste content the freeze-thaw resistance starts to decrease but remains close to the resistance after 900 freeze-thaw cycles.

Higher tire waste content reduces thermal conductivity of concrete almost linearly. Tire waste added at $10 \%$ reduces the coefficient of thermal conductivity by approximately $35 \%$.

Concrete with waste tire cord yarn has much higher post-crack toughness than concrete without this waste.

\section{Acknowledgments}

The authors gratefully acknowledge the help of the VGTU Civil Engineering Centre in providing the laboratory equipment, which was used in the present investigation.

\section{References}

Aiello, M. A.; Leuzzi, F. 2010. Waste tyre rubberized concrete, properties at fresh and hardened state, Waste Management 30: $1696-1704$.

http://dx.doi.org/10.1016/j.wasman.2010.02.005

Aiello, M. A.; Leuzzi, F.; Centonze, G.; Maffezzoli, A. 2009. Use of steel fibres recovered from waste tyres as reinforcement in concrete: pull-out behaviour, compressive and flexural strength, Waste Management 29(6): 1960-1970. http://dx.doi.org/10.1016/j.wasman.2008.12.002

Albano, C.; Camacho, N.; Reyes, J.; Feliu, J. L.; Hernandez, M. 2005. Influence of scrap rubber addition to Portland concrete composites: destructive and non-destructive testing, Composite Structures 71: 439-446.

http://dx.doi.org/10.1016/j.compstruct.2005.09.037

Centonze, G.; Leone, M.; Aiello, M. A. 2012. Steel fibers from waste tires as reinforcement in concrete: a mechanical characterization, Construction and Building Materials 36(11): 46-57.

http://dx.doi.org/10.1016/j.conbuildmat.2012.04.088
El-Gammal, A.; Abdel-Gawad, A. K.; El-Sherbini, Y.; Shalaby, A. 2010. Compressive strength of concrete utilizing waste tire rubber, Journal of Emerging Trends in Engineering and Applied Sciences 1(1): 96-99.

EN 197-1:2011. Cement - Part 1: Composition, specifications and conformity criteria for common cements. $2011.38 \mathrm{p}$.

EN 12620:2003+A1:2008. Aggregates for concrete. 2008. 49 p.

EN 1097-2. Tests for mechanical and physical properties of aggregates - Part 2: Methods for the determination of resistance to fragmentation. $2010.34 \mathrm{p}$.

EN 1097-3:2002. Tests for mechanical and physical properties of aggregates - Part 3: Determination of loose bulk density and voids. $2002.14 \mathrm{p}$.

EN 1367-2:2010. Tests for thermal and weathering properties of aggregates - Part 2: Magnesium sulfate test. 2010. 15 p.

EN 933-1:2012. Tests for geometrical properties of aggregates Part 1: Determination of particle size distribution - Sieving method. 2012. $18 \mathrm{p}$.

EN 934-2:2009. Admixtures for concrete, mortar and groutPart 2: Concrete admixtures - Definitions, requirements, conformity, marking and labelling. 2009. $23 \mathrm{p}$.

EN 1008:2005. Mixing water for concrete - Specification for sampling, testing and assessing the suitability of water, including water recovered from processes in the concrete industry, as mixing water for concrete. $2005.17 \mathrm{p}$.

EN 12390-2:2009. Testing hardened concrete - Part 2: Making and curing specimens for strength tests. 2009. $6 \mathrm{p}$.

EN 12390-3:2009. Testing hardened concrete - Part 3: Compressive strength of test specimens. $2009.18 \mathrm{p}$.

EN 12390-7:2009. Testing hardened concrete - Part 7: Density of hardened concrete. 2009. $10 \mathrm{p}$.

EN 1745:2012. Masonry and masonry products - Methods for determining thermal properties. $2012.76 \mathrm{p}$.

EN 14651+A1:2007. Test method for metallic fibre concrete - Measuring the flexural tensile strength (limit of proportionality (LOP), residual). 2007. 17 p.

Ganjian, E.; Khorami, M.; Maghsoudi, A. A. 2009. Scrap-tyrerubber replacement for aggregate and filler in concrete, Construction and Building Materials 23: 1828-1836. http://dx.doi.org/10.1016/j.conbuildmat.2008.09.020

Garrick, G. M. 2005. Analysis and testing of waste tire fiber modified concrete: Thesis. Louisiana State University. 65 p.

Hernandez-Olivares, F.; Barluenga, G.; Bollati, M.; Witoszek, B. 2002. Static and dynamic behaviour of recycled tyre rubberfilled concrete, Cement and Concrete Research 32(10): 15871596. http://dx.doi.org/10.1016/S0008-8846(02)00833-5

Kerševičius, V.; Skripkiūnas, G. 2001. Use of rubber waste in Portland cement concrete, Environmental Research Engineering and Management 4(18): 40-45.

Li, G.; Garrick, G; Eggers, J.; Abadie, Ch.; Stubblefield, M. A.; Pang, S. S. 2004a. Waste tire fiber modified concrete, Composites Part B: Engineering 35(4): 305-312. http://dx.doi.org/10.1016/j.compositesb.2004.01.002

Li, G.; Stubblefield, M. A.; Garrick, G.; Eggers, J.; Abadie, Ch.; Huang, B. 2004b. Development of waste tire modified concrete, Cement and Concrete Research 34(12): 2283-2289. http://dx.doi.org/10.1016/j.cemconres.2004.04.013

Mačiulaitis, R. 1996. Vilnius: Technika. 132 p.

Nagrockienė, D.; Skripkiūnas, G.; Girskas, G. 2011. Predicting 
frost resistance of concrete with different coarse aggregate concentration by porosity parameters, Materials Science 17(2): 203-207. http://dx.doi.org/10.5755/j01.ms.17.2.493

Oikonomou, N.; Mavridou, S. 2009. Improvement of chloride ion penetration resistance in cement mortars modified with rubber from worn automobile tires, Cement and Concrete Composites 31: 403-407.

http://dx.doi.org/10.1016/j.cemconcomp.2009.04.004

Pacheco-Torgal, F.; Ding, Y.; Jalali, S. 2012. Properties and durability of concrete containing polymeric wastes (tyre rubber and polyethylene terephthalate bottles): An overview, Construction and Buildings Materials 30: 714-724. http://dx.doi.org/10.1016/j.conbuildmat.2011.11.047

Papakonstantinou, Ch. G.; Tobolski, M. J. 2006. Use of waste tire steel beads in Portland cement concrete, Cement and Concrete Research 36(9): 1686-1691.

http://dx.doi.org/10.1016/j.cemconres.2006.05.015

Pehlken, A.; Muller, D. H. 2009. Using information of the separation process of recycling scrap tires for process modelling, Resources, Conservation and Recycling 54: 140-148. http://dx.doi.org/10.1016/j.resconrec.2009.07.008

Sang Son, K.; Hajirasouliha, I.; Pilakoutas, K. 2011. Strength and deformability of waste tyre rubber-filled reinforced concrete columns, Construction and Building Materials 25: 218-226. http://dx.doi.org/10.1016/j.conbuildmat.2010.06.035

Sienkiewicz, M.; Kucinska-Lipka, J.; Janik, H.; Balas, A. 2012.
Progress in used tyres management in the European Union: A review, Waste Management 32(10): 1742-1751. http://dx.doi.org/10.1016/j.wasman.2012.05.010

Skripkiunas, G.; Vaitkevicius, V.; Dauksys, M.; Grinys, A. 2008. Prediction of concrete freezing-thawing resistance, in Proceedings of the International Conference, 8-9 July 2008, University of Dundee, Scotland, 317-324.

Skripkiūnas, G. 2007. The structure and properties of construction conglomerates. Kaunas: Vitae Litare. 334 p. (in Lithuanian).

Skripkiūnas, G.; Grinys, A.; Černius, B. 2007. Deformation properties of concrete with rubber waste additives, Materials Science 13(3): 219-223.

Stankevičius, V.; Skripkiūnas, G.; Grinys, A.; Miškinis, K. 2007. Acoustical characteristics and physical-mechanical properties of plaster with rubber waste additives, Materials Science 13(4): 304-309.

Toutanji, H. A. 1996. The use of rubber tire particles in concrete to replace mineral aggregates, Cement and Concrete Composites 18: 135-139. http://dx.doi.org/10.1016/0958-9465(95)00010-0

Zhang, Y. M.; Chen, X. S.; Chen, B.; Sun, W. 2006. Dry shrinkage, frost resistance and permeability of rubber included concrete, Key Engineering Materials 302-303: 120-124. http://dx.doi. org/10.4028/www.scientific.net/KEM.302-303.120

Jurgita MALAIŠKIENĖ, Civil Engineer, Dr.sc.ing., research worker, VGTU, Faculty of Civil Engineering, Department of Building Materials. Publications: 25 scientific and methodological works. Research interests include creating and analysing physical, mechanical, structural, etc. properties and possibilities of using new conglomerates (ceramics, concrete, etc.) made of local recourses having different forms of waste. Address: Saulètekio Av. 11, Vilnius LT-10223, Lithuania.

Džigita NAGROCKIENĖ, Civil Engineer, Dr.sc.ing., Assoc. Prof, VGTU, Faculty of Civil Engineering, Department of Building Materials. Publications: 30 scientific and methodological works. Research interests include creating and analysing physical, mechanical, structural, etc. properties of concrete, frost resistance and durability of building materials. Address: Sauletekio Av. 11, Vilnius LT-10223, Lithuania.

Gintautas SKRIPKIŪNAS, Civil Engineer, Dr.sc.ing., Prof., VGTU, Faculty of Civil Engineering, Department of Building Materials. Publications: 50 scientific and methodological works. Research interests include material science, concrete technology, rheological, mechanical, structural properties of concrete, durability of concrete, concrete modification. Address: Saulètekio Av. 11, Vilnius LT-10223, Lithuania. 